\author{
Sławomir Dorocki \\ Pawel Brzegowy \\ Uniwersytet Pedagogiczny \\ im. Komisji Edukacji Narodowej \\ w Krakowie
}

\title{
Uwarunkowania przestrzennego zróżnicowania postaw przedsiębiorczych we Francji
}

\section{Educational conditions of spatial diversity of entrepreneurial attitudes in France}

\begin{abstract}
Streszczenie
W poniższym tekście podjęto próbę przedstawienia uwarunkowań kształcenia z zakresu przedsiębiorczości oraz odpowiedzi na pytanie o przestrzenne zróżnicowanie postaw przedsiębiorczych we Francji. Analizy problemu dokonano na podstawie literatury tematu oraz danych statystycznych zaczerpniętych z instytucji rządowych Francji. W odniesieniu do przeprowadzonych badań należy stwierdzić, że pomimo wprowadzonych w ostatnich latach zmian w kształceniu przedsiębiorczości (głównie rozwój ducha przedsiębiorczości) nauczanie w tym zakresie jest wciąż niedostateczne, zwłaszcza w odniesieniu do współczesnych wyzwań gospodarczych. We Francji istnieją znaczące dysproporcje w przejawach przedsiębiorczości. Na potrzeby poniższych badań za jeden z nich przyjęto zakładanie nowych podmiotów gospodarczych. Nierówności te najsilniej uwidoczniły się w sytuacji ekstremalnej, z początkiem światowego kryzysu finansowego w 2008 r. Najbardziej przedsiębiorczymi obszarami pozostawały wówczas regiony dużych ośrodków miejskich, regiony z dużym udziałem sektora wysokiej techniki oraz obszary nadmorskie. Zestawienie danych o wielkości nowo powstałych firm z danymi o udziale MŚP w gospodarce jednostek oraz udziale ludności z wyższym wykształceniem wskazuje na wpływ tych cech na postawy przedsiębiorcze ludności Francji.
\end{abstract}

\begin{abstract}
In the following text, an attempt was made to present the conditions for entrepreneurship training and to answer the question of spatial variability of entrepreneurial attitudes in France. The problem analysis was made on the basis of literature on the subject and statistical data derived from the French government. With regard to the performed analyses, it should be noted that, despite the changes implemented in recent years in entrepreneurship training (mainly developing the spirit of entrepreneurship), teaching in this area is still insufficient, especially in respect of today's economic challenges. In France, there are significant disparities in manifestation of entrepreneurship, which for the purpose of the analysis is the establishment of new businesses. These disparities were most evident in an extreme situation, at the beginning of the global financial crisis in 2008. The most entrepreneurial regions were large urban centres, regions with a high share of high-tech industry and coastal areas. Comparing data on the size of start-up companies with the data on the participation of SMEs in the economy of the region and the share of population with higher education shows the influence of these characteristics on the entrepreneurial attitudes of the French population.
\end{abstract}


Słowa kluczowe: Francja; kształcenie; MŚP; przedsiębiorczość; samozatrudnienie

Key words: entrepreneurship; France; education, SME, self-employed

\section{Wprowadzenie}

Przedsiębiorczość ma wiele różnorodnych definicji. W większości wypadków termin przedsiębiorczość odnosi się do ogółu przejawów aktywnych postaw społecznych. Określa się nim także „chęć do aktywnej partycypacji w życiu społeczno-gospodarczym, jak i zdolność oraz wolę do założenia i prowadzenia własnego przedsiębiorstwa” (Brzozowski, 2007; Rachwał, 2005a, 2006b). W ujęciu tym przedsiębiorczość może być traktowana jako jeden z podstawowych czynników rozwoju społeczno-gospodarczych układów przestrzennych różnej skali (Kurek, Rachwał, 2010; Naudé, 2008; Zioło, 2006, 2007, 2008; Dorocki, Kilar, Rachwał, 2012). Również według definicji francuskiej literatury naukowej, przedsiębiorczość przyjmuje się za ,zbiór zachowań, umiejętności i cech wykorzystywanych do zarządzania, organizowania, tworzenia przedsiębiorstw i innowacji, w sytuacjach wymagających podjęcia ryzyka i analizy wielu zmiennych" (Bechard, 1998; Fayolle, 2000; Sénicourt, Verstraete, 2000).

W powyższych ujęciach przedsiębiorczość odgrywa zatem główną rolę w aktywowaniu wzrostu gospodarczego i generowaniu impulsów do transformowania struktury gospodarczej oraz pozyskiwania nowych źródeł wzrostu wydajności pracy, która leży u podstaw konkurencyjności (Dorocki, Kilar, Rachwał, 2012). Współcześnie, w czasie trwającego od początku 2008 r. kryzysu gospodarczego, którego skutki można zaobserwować w spadku produkcji i ograniczeniu zatrudnienia, aktywne postawy przedsiębiorcze, w tym praca na własny rachunek, okazują się dla wielu osób jedynym możliwym sposobem zapewnienia sobie godziwych środków do życia.

Jak zauważył Michel Marchesnay (2008), w społeczeństwie francuskim przedsiębiorczość, zwłaszcza w odniesieniu do działalności małych i średnich firm, historycznie nie cieszy się społeczną rewerencją. Przedsiębiorcy we Francji nie mogli liczyć na nobilitację i uznanie obywatelskie. Dziejowe potwierdzenie braku aprobaty dla inicjatyw przedsiębiorczych u Francuzów można odnaleźć w dziele wybitnego przedstawiciela narodowej myśli naturalistycznej Gustava Flauberta Dictionnaire des idées reçues (1913), w którym dowodził on, iż Francuzi wyzbyci są ducha przedsiębiorczości (Le Français: pas d'esprit d'entreprise). Współczesną konfirmacją powyższego twierdzenia są dane zawarte w raporcie Global Entrepreneurship Monitor z 2012 r., potwierdzające absencję postaw przedsiębiorczych we Francji. Pryncypialnej determinanty tej sytuacji upatruje się w przyjętych przez Francuzów normach społeczno-kulturowych, które hamują rozwój zachowań przedsiębiorczych. Analizując ścieżkę kariery zawodowej Francuzów, można zauważyć awersję dla prywatnych (egoistycznych) inicjatyw gospodarczych oraz historyczne uznanie dla instytucji państwowych (działających na rzecz dobra kraju), które kreują elitę społeczną narodu (l'élite de la nation). Innymi barierami dla rozwoju przedsiębiorczości we Francji wzmiankowanymi w raporcie są: powszechna obawa przed porażką, brak chęci do podejmowania ryzyka, a także niechęć w podejmowaniu samodzielnych działań. Wśród pozostałych czynników wpływających na niski stopień przedsiębiorczości Francuzów należy wymienić brak dostatecznej wiedzy ekonomicznej, zwłaszcza na temat zakładania i prowadzenia własnej firmy, co wiąże się z kwestią kształcenia w zakresie przedsiębiorczości, głównie na poziomie szkół wyższych. Kolejną niesprzyjającą cechą francuskiego modelu przedsiębiorczości jest jej rozwój wyłącznie w „niskich” usługach, które często tworzone są przez cudzoziemców. Jednakże według ekonomisty, Edmunda Phelpsa, we Francji to głównie trwałość modelu korporacyjnego generuje zanik ducha przedsiębiorczości oraz motywacji do pracy i innowacji. W przekonaniu noblisty sytuacja ta utrwalana jest 
przez egzemplaryczny system edukacji, który znacznie ogranicza kreatywność społeczeństwa. Odpowiedzią państwa na powyższe zarzuty wobec modelu szkolnictwa może być wspólny protokół francuskiego Ministerstwa Edukacji (Ministère de la jeunesse, de l'éducation nationale et de la recherche, le ministère délégué à l'enseignement scolaire) oraz Ministerstwa Gospodarki (Secrétaire d'État aux PME, au commerce et à l'artisanat) z 2003 r. traktujący o rozwoju ducha przedsiębiorczości wśród ludzi młodych (Développer l'esprit d'entreprendre: une ambition partagée). W powyższym sprawozdaniu za główny cel obrano ożywienie ducha przedsiębiorczości, którego wyrazem pozostawać miało utworzenie miliona nowych firm w okresie najbliższych pięciu lat. Pragnąc urzeczywistnić przyjęte założenie, zainaugurowano działania na rzecz propagowania wiedzy na temat biznesu, poprawy wizerunku przedsiębiorstw i sektorów zawodowych oraz zachęcano młodych ludzi do podejmowania inicjatyw gospodarczych. Niezależnie od krajowej kampanii promującej przedsiębiorczość, w ramach podjętych starań znalazło się: opracowanie wykazu dobrych praktyk z zakresu kształcenia przedsiębiorczości, ogłoszenie konkursu na najlepsze projekty w obszarze jej nauczania, realizacja tematów z dziedziny przedsiębiorczości w istniejących celach nauczania oraz wspieranie nauczycieli poprzez kursy i szkolenia. Z dalszych czynności trzeba wspomnieć o organizowaniu sieci koordynatorów nauczania przedsiębiorczości w systemie edukacji, podejmujących współpracę z partnerami ze świata gospodarki, oraz powołaniu Krajowej Komisji ds. Promocji Przedsiębiorczości (Commission nationale de promotion de l'esprit d'entreprendre). Decyzję o intensywnym popularyzowaniu działań na rzecz kształtowania postaw przedsiębiorczych wzmógł zapoczątkowany w 2008 r. światowy kryzys finansowy. Prezydent François Hollande, w swym wystąpieniu z 2013 r., stwierdził, że pierwszą rolą szkoły jest stymulowanie narodowej przedsiębiorczości.

Na podstawie powyższych przesłanek w niniejszej pracy podjęto problematykę uwarunkowań rozwoju przedsiębiorczości w aspekcie jej nauczania we Francji oraz przestrzennego zróżnicowania postaw przedsiębiorczych Francuzów w odniesieniu do liczby nowo powstałych firm. Analizy problemu dokonano na podstawie literatury tematu oraz danych statystycznych zaczerpniętych z francuskiej Agencji Kreowania Przedsiębiorczości (Agence pour la création d'entreprises, APCE), Francuskiego Instytutu Statystycznego (L'Institut national de la statistique et des études économiques, Insee) oraz danych publikowanych przez Eurostat. Regionalizacji Francji dokonano na podstawie podziału departamentalnego (NUTS 3).

\section{Nauczanie przedsiębiorczości we Francji}

Nauczanie przedsiębiorczości jest jedną z najbardziej oczywistych form przygotowujących ludzi do tworzenia firm. Jest procesem, w którym uczniowie i studenci nabywają określonych umiejętności, zaś przez kształtowanie ich postawy wpływa się również na wybór przyszłych ścieżek zawodowych. Przytoczona we wstępie francuska definicja przedsiębiorczości podkreśla jej wieloaspektowość. Stąd we Francji wskazuje się na potrzebę interdyscyplinarnego podejścia w nauczaniu przedsiębiorczości.

Nauczanie przedsiębiorczości nad Sekwaną do niedawna odbywało się jedynie na V, najwyższym poziomie szkolnictwa. Do kluczowych celów tej edukacji Azzedine Tounés (2003) zaliczył: podniesienie świadomości przedsiębiorczej, kształtowanie umiejętności w obszarach działań na rzecz przedsiębiorczości w celu zachęcania do tworzenia własnego biznesu (z uwzględnieniem specyfiki zawodu, specjalizacji) oraz wspieranie i monitorowanie projektów przedsiębiorczych (doradztwo). W praktyce ok. 80\% zajęć z przedsiębiorczości prowadzonych w wyższych szkołach inżynierskich (DUT i BTS) to rodzaj wiedzy (świadomości), podczas gdy w szkołach ekonomicznych i uniwersytetach ten wariant stanowi odpowiednio 
ok. $70 \%$ i $60 \%$. Ogólnie przedsiębiorczość wypełnia ok. 25\% treści programów i kursów oferowanych za pośrednictwem szkół ekonomicznych, 20\% treści w szkołach inżynierskich i 16\% treści świadczonych przez uniwersytety.

Współcześnie w nauczaniu przedsiębiorczości we Francji postuluje się rezygnację z tradycyjnego paradygmatu nauki ekonomii (finanse, podatki, marketing, itp.) na rzecz rozwijania ducha przedsiębiorczości. Odbywa się to dzięki realizowaniu zadań praktycznych, przyswajanych przez eksperymentowanie. Intencją takich działań jest kreowanie postaw przedsiębiorczych w sytuacji niepewności, rozbudzanie potrzeby podejmowania ryzyka i wykazywania kreatywności oraz inicjatywy. Powyższa metoda prób i błędów ma w jak najwierniejszy sposób odtworzyć warunki, z którymi spotkają się absolwenci we współczesnej rzeczywistości gospodarczej. Wśród zalecanych technik nauczania przedsiębiorczości we Francji znalazła się metoda projektu, w ramach której zespoły realizują zadania nie w sposób przekrojowy, lecz funkcjonalny. W dążenia do osiągnięcia założonego celu projektu wykorzystywane są interdyscyplinarne umiejętności uczniów (np. manualne, techniczne, z zakresu zarządzania), współpracujących w ramach wspólnego zadania. Metoda problemowa przyczynia się do wzajemnego uczenia się, wymiany wiedzy i umiejętności między studentami a wykładowcami oraz potencjalnymi partnerami (przedsiębiorcami) biorącymi udział w danym projekcie. W ujęciu tym w głównej mierze zwraca się uwagę na potrzebę zapewnienia uczniom dostępu do zasobów i umiejętności innych osób (np. ekspertów).

Jak wspomniano powyżej, nauczanie przedsiębiorczości powinno się składać z etapów, na których następowałoby przekazywanie wiedzy i umiejętności potrzebnych do realizacji konkretnych projektów (tab. 1). Nabywcami wiedzy są w takim wypadku osoby wykonujące prace zlecone oraz liderzy. Podkreśla się, iż nie wszystkie osoby mają odpowiednie predyspozycje do tworzenia firm i zarządzania nimi. Natomiast wszyscy potrzebują wiedzy i umiejętności pozwalających na swobodne poruszanie się we współczesnym świecie biznesu.

Tab. 1. Analiza etapów nauczania przedsiębiorczości we Francji

\begin{tabular}{|c|c|c|}
\hline FAZA I & FAZA II & FAZA III \\
\hline świadomość i informacja & specjalizacja & doradztwo i wsparcie \\
\hline $\begin{array}{l}\text { Rozwój wiedzy ogólnej na } \\
\text { temat przedsiębiorczości } \\
\text { Odbiorca: szeroki } \\
\text { Cele: Po co? Jakie są cele? Jakie } \\
\text { korzyści możemy czerpać? } \\
\text { Jakie czynniki wpływają? Jakie } \\
\text { są zagrożenia i wyzwania? } \\
\text { Jakie są konsekwencje dla życia } \\
\text { przedsiębiorcy, jego rodziny } \\
\text { i kręgu przyjaciół? }\end{array}$ & $\begin{array}{l}\text { Rozwój postaw i umiejętności } \\
\text { Odbiorca: osoby, które chcą } \\
\text { pracować w obszarach przedsię- } \\
\text { biorczości i tworzenia przedsię- } \\
\text { biorstw } \\
\text { Cele: Jak działać? Co chcemy } \\
\text { osiągnąć? Jakie są konkretne } \\
\text { metody i narzędzia? }\end{array}$ & $\begin{array}{l}\text { Rozwój zachowań przedsiębior- } \\
\text { czych } \\
\text { Odbiorca: kierownicy projek- } \\
\text { tów, liderzy } \\
\text { Cele: Jak sformalizować } \\
\text { projekt? Czy to się uda? Jak } \\
\text { uzyskać dostęp do różnych } \\
\text { zasobów, aby osiągnąć cel? }\end{array}$ \\
\hline
\end{tabular}

Źródło: opracowanie własne na podstawie A. Tounés (2003).

Obowiązkowe kursy z przedsiębiorczości odbywają się w ramach studiów wyższych, jednakże od 2004 r. wprowadzono dobrowolny moduł découverte professionnelle (odkrywanie biznesu/zawodu) realizowany w trzeciej klasie collège. Ten opcjonalny moduł ma na celu zapoznanie uczniów ze światem biznesu oraz uwarunkowaniami społeczno-ekonomicznymi. Informacje te mają przygotować młodych ludzi do aktywności zawodowej. Moduł realizowany 
jest w wymiarze trzech godzin tygodniowo. W trakcie zajęć poruszane są następujące tematy: praktyczne zrozumienie realiów i uwarunkowań świata biznesu oraz pracy zawodowej, a także poznanie wymaganych szkoleń i kwalifikacji, które prowadzą do zdobycia określonego zawodu. W ramach lekcji uczniowie poznają różne branże i profesje oraz formy organizacji pracy (np. samozatrudnienie), zapoznają się z różnymi drukami i dokumentami, spotykają z profesjonalistami (praktykami). Celem zajęć może być zbadanie przebiegu kariery zawodowej np.: pilota, piekarza, webmastera czy pielęgniarki, lub odpowiedź na pytanie, jak zorganizować pracę w dużej lub małej firmie, administracji czy laboratorium badawczym. Ponadto słuchacze dowiadują się, jak zdobyć kwalifikacje potwierdzone przez główne dyplomy zawodowe: (CAP, BAC, BTS, master, ingénieur) oraz w jaki sposób zdobyć te uprawnienia (szkolenie wstępne, kształcenie ustawiczne), a także gdzie pozyskać szczegółowe informacje (IOC ONISEP itd.). Przedmiot realizowany jest w formie międzyklasowej i nadzorowany przez wielodyscyplinarny zespół edukacyjny (m.in. nauczycieli, bibliotekarzy, doradców zawodowych, psychologów). Zalecanymi typami zajęć dydaktycznych są: badanie i analiza dokumentów, pism i notatek z zebranych samodzielnie przez uczniów informacji, wywiady ze specjalistami, warsztaty, wizyty, obserwacje lub staże w przedsiębiorstwach, administracji publicznej czy placówkach ochrony zdrowia.

Moduł découverte professionnelle może być również realizowany w wymiarze sześciu godzin tygodniowo. Zaprojektowany jest na tej samej zasadzie, co opcja trzygodzinna, jednakże z większą ilością czasu poświęconego na praktykę (w firmach, szkołach zawodowych lub w formie staży w ośrodkach szkoleniowych), z dużym naciskiem na realizację wybranego projektu, np. planowanie, założenie i organizacja własnego przedsiębiorstwa. Opcja ta przeznaczona jest głównie dla uczniów klas kolegialnych, którzy nie będą kontynuować swojej edukacji i w niedługim czasie zdecydują się na podjęcie pracy. Należy podkreślić, iż prezentowany projekt jest współrealizowany w kooperacji z organizacjami zrzeszającymi przedsiębiorców i ludzi biznesu, m.in. Mouvement des entreprises de France (MEDEF), la Confédération générale des petites et moyennes entreprises (CGPME), l'Union professionnelle artisanale (UPA), l'Assemblée permanente des chambres de métiers (APCM), co pozwala na ścisłe powiązanie treści nauczania z potrzebami przedsiębiorców i współczesnymi wyzwaniami świata biznesu. W 2013 r. moduł oferowany był przez ok. 90\% szkół we Francji i obejmował 12\% ogółu uczniów.

Wśród zmian, które miały miejsce w nauczaniu przedsiębiorczości we Francji po 2008 r., można wskazać na położenie większego nacisku na współpracę z przedsiębiorcami oraz kształtowanie ducha przedsiębiorczości kosztem nauczania suchej wiedzy ekonomicznej. W myśl tej zasady Patrick Rey z Toulouse School of Economics postulował, żeby przedsiębiorcy stawali się nauczycielami/trenerami, podczas gdy nauczyciele/trenerzy - przedsiębiorcami (Lavoie, 2013). Postulowano, aby nauka przedsiębiorczości odbywała się w systemie realizacji projektów przy wparciu różnych podmiotów zewnętrznych (instytucji, przedsiębiorstw, trenerów). Działania te mają na celu aktywizację ekonomiczną młodzieży oraz szerzenie zasad równości (égalité) związanych z eliminowaniem barier finansowych, społecznych, kulturowych, geograficznych i psychologicznych, tak aby podejmowanie działalności gospodarczej było we Francji bardziej demokratyczne.

Obok projektów rządowych, mających za zadanie krzewienie ducha przedsiębiorczości, we Francji podejmowane są również inicjatywy prywatne. Przykładem takiej operacji może być realizowany od 2008 r. projekt Philippe Hayata: 100000 Entrepreneurs. W projekcie tym partycypuje ok. 4 tys. wolontariuszy (przedsiębiorców), których zadaniem jest rozwijanie ducha przedsiębiorczości przez kontakty z młodzieżą. 
Działania te, zgodnie z wypowiedzią Minister do spraw MŚP, Innowacji i Cyfryzacji Fleur Pellerin, przynoszą wymierne wyniki. Według przeprowadzonych badań obecnie $61 \%$ Francuzów pozytywnie odnosi się do wizerunku przedsiębiorcy, a 87\% uważa, że przedsiębiorczość tworzy nowe miejsca pracy (Visot, 2013).

\section{Przestrzenne zróżnicowanie postaw przedsiębiorczych we Francji}

W poprzedniej części pracy przestawiono działania mające na celu rozwój ducha przedsiębiorczości wśród młodych Francuzów, natomiast w drugiej części opracowania analizie zostaną poddane przejawy przedsiębiorczości we Francji. Jako wskaźnik przedsiębiorczości przyjęto liczbę nowo powstałych firm. Wielkość rejestracji nowych podmiotów gospodarczych zależy od wielu zmiennych. Warunkowana jest ona zarówno przez sytuację gospodarczą i polityczną, panującą w danym kraju i na świecie, jak i przez uwarunkowania prawne i finansowe. Jednakże to w głównej mierze aktywna postawa społeczeństwa, odnosząca się do inicjatyw gospodarczych, wpływa na liczbę nowo powstałych firm.

W okresie od stycznia 2000 r. do początków 2008 r. we Francji następował powolny wzrost liczby nowych firm (ryc. 1). W 2008 r. - wraz z rozwojem kryzysu światowego - odnotowano spadek ich liczby. Szczególnie widoczne było to w II poł. omawianego roku. Początek 2009 r. przyniósł gwałtowny rozwój rejestracji nowych podmiotów gospodarczych. Sytuacja ta wynikała po części z wprowadzonych przez państwo ułatwień prawnych i zachęt fiskalnych mających aktywizować obywateli do samozatrudnienia. Dynamiczny wzrost liczby nowo zakładanych firm trwał do 2010 r., by w kolejnych latach ustabilizować się na średnim poziomie 4,5 tys., z widoczną tendencją spadkową w I poł. $2013 \mathrm{r}$.

Wzrost udziału małych firm, głównie jednoosobowych, od 2009 r. widoczny jest w zestawieniu struktury własnościowej nowo powstałych firm. W latach 2000-2008 udział przedsiębiorstw prywatnych nie przekraczał 58\%, podczas gdy w latach 2009 i 2010 przyjął wartość ponad 73\%, by następnie zredukować się do poziomu 70\%. Wynikiem takiej sytuacji może być samozatrudnienie jako odpowiedź na brak pracy i wzrost bezrobocia (Dorocki, 2011). Wraz z poprawą warunków na rynku pracy część osób mogła zlikwidować swoje firmy, które w wielu wypadkach okazały się bardzo mało dochodowe lub deficytowe (za: La destruction de l'esprit d'entreprise en France).

Ryc. 1. Liczba nowo powstałych przedsiębiorstw we Francji w latach 2000-2013

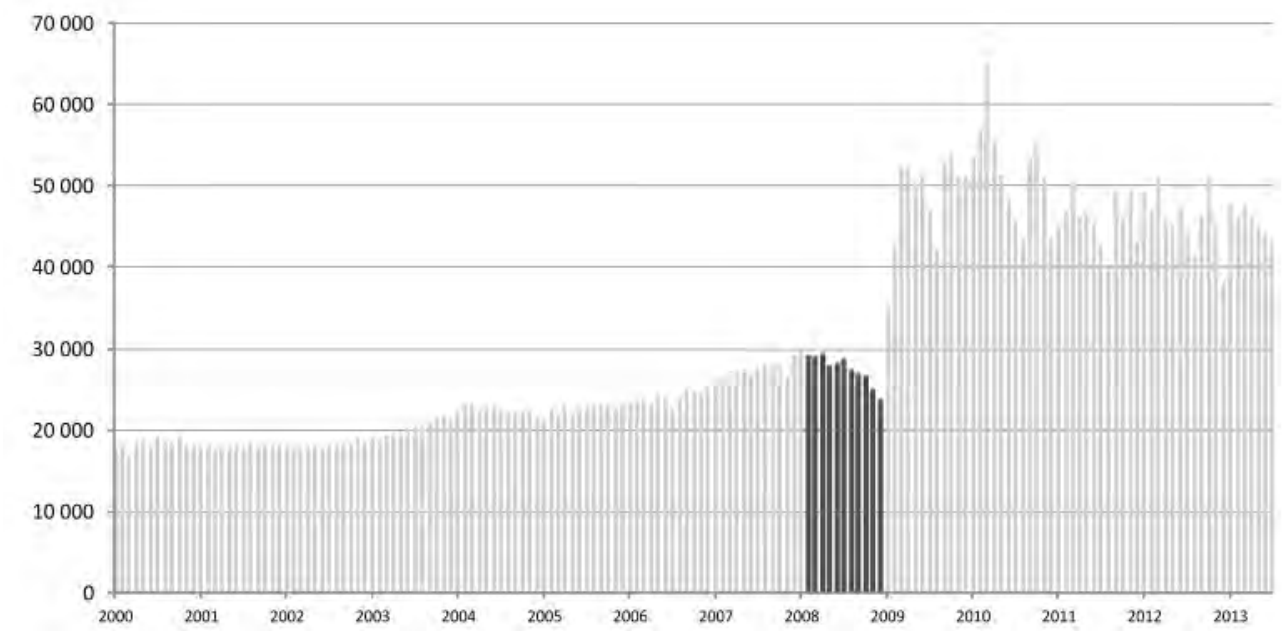

Źródło: opracowanie własne na podstawie danych APCE. 
Ryc. 2. Struktura własnościowa (A) i branżowa (B) nowo powstałych firm we Francji w latach 2000-2013
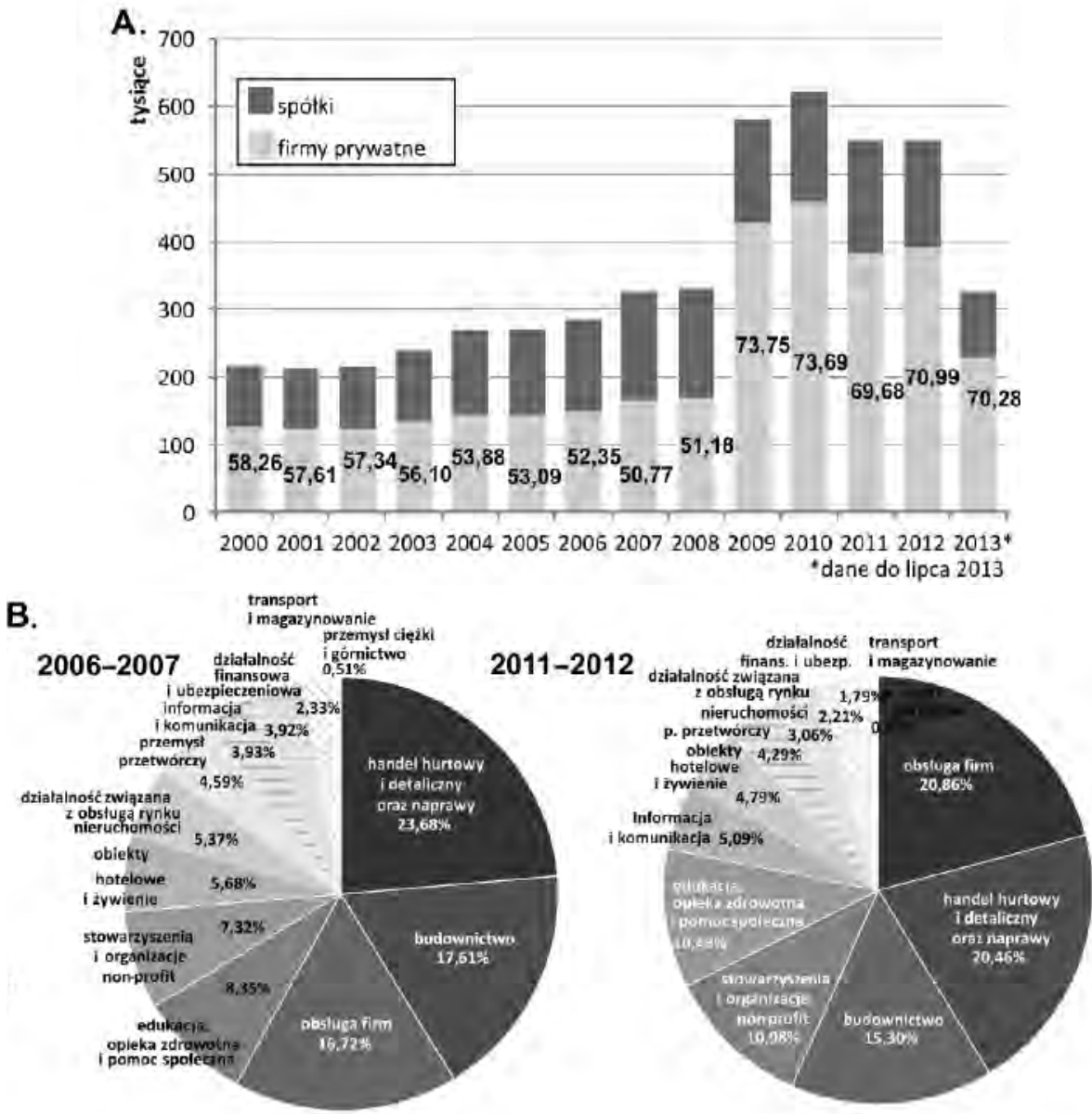

-dane do lipca 2013

Źródło: opracowanie własne na podstawie danych APCE.

Analizując strukturę branżową nowo powstałych przedsiębiorstw w okresie przed kryzysem i po nim, można zauważyć niewielkie przesunięcia sektorowe (ryc. 2). W latach 2011-2012 w stosunku do lat 2006-2007 nastąpił spadek liczby rejestracji firm, w szczególności z sektora handlu (z 23,7\% do 20,5\%), sektora budownictwa (z 16,7\% do 15,3\%) oraz w sekcjach: obiektów hotelowych i gastronomii, obsługi rynku i nieruchomości, a także działalności finansowej i ubezpieczeniowej. Tymczasem wzrost udziału wśród nowo powstałych firm odnotowały podmioty związane z obsługą przedsiębiorstw (z 16,7\% do 20,8\%), stowarzyszenia i organizacje non-profit (z 7,3\% do 11,0\%), firmy skojarzone z edukacją, ochroną zdrowia i pomocą społeczną (7,3\% do 10,5\%), a także firmy z branży informatycznej i komunikacyjnej oraz w niewielkim stopniu prowadzące działalność w sektorze przemysłowym. Zmiany w strukturze branżowej nowo powstałych firm są odzwierciedleniem sytuacji na francuskim rynku, w którym największy spadek zatrudnienia odnotowały przedsiębiorstwa z sektora budownictwa, a najmniejszy - firmy handlowe. 
Poddając analizie przestrzenne zróżnicowanie tempa zmiany liczby nowo powstałych firm we Francji, wykorzystano podział na departamenty. Analizę ograniczono do lat 2008 i 2009 , ponieważ wówczas nastąpiło największe zróżnicowanie liczby powołanych do życia nowych podmiotów gospodarczych w departamentach. Miało to związek z ekstremalną sytuacją spowodowaną kryzysem światowym.

W roku wybuchu kryzysu największy wzrost liczby nowo powstałych przedsiębiorstw w stosunku do roku poprzedniego odnotowały departamenty metropolii Paryża Hauts-de-Seine (1757\%), Paris (959\%) oraz Oise (328\%), Essonne (318\%) i Loiret (213\%) (ryc. 3). Jednakże w tym samym czasie wschodnie departamenty regionu Wielkiego Paryża, np. Seine-et-Marne, Val-de-Marne i Val-d'Oise, odnotowały ponad 60-procentowy spadek. Innymi regionami o wysokim wzroście liczby nowo zarejestrowanych podmiotów gospodarczych były obszar śródziemnomorski (od Haute Garonne po Var) z wyróżniającym się departamentem Hérault (820\%), obszar Wielkiego Lyonu (od Puy-de-Dôme po Haute Savoie) z największą wartością wzrostu w departamencie Isère (775\%), północna część Lotaryngii i Alzacji (Meurthe-et-Moselle 396\%) oraz zachodnie departamenty Francji usytuowane wzdłuż Loary i region Nord. Wymienione jednostki, które pomimo kryzysu gospodarczego odnotowały tak wysoki wzrost inicjatyw gospodarczych, zawdzięczały to głównie postawom przedsiębiorczym tamtejszej ludności (stolica i regiony nadmorskie), dominacji usług i handlu (wielkie miasta), obecności sektora wysokiej technologii (południe Francji i Alpy) oraz tradycjom przemysłowym, przejawiającym się obecnością specjalistów i szkół zawodowych (na wschodzie i północy Francji) (Davezies, 2012). Spadek nieprzekraczający 90\% odnotowały natomiast przede wszystkim regiony środkowej Francji: Poitou-Charentes na zachodzie i Burgundii na wschodzie, Champagne-Ardenne, Normandii, Masywu Centralnego i południowej Akwitanii oraz Korsyki.

Ryc. 3. Tempo zmian liczby nowo powstałych firm w latach 2008 i 2009 w departamentach Francji

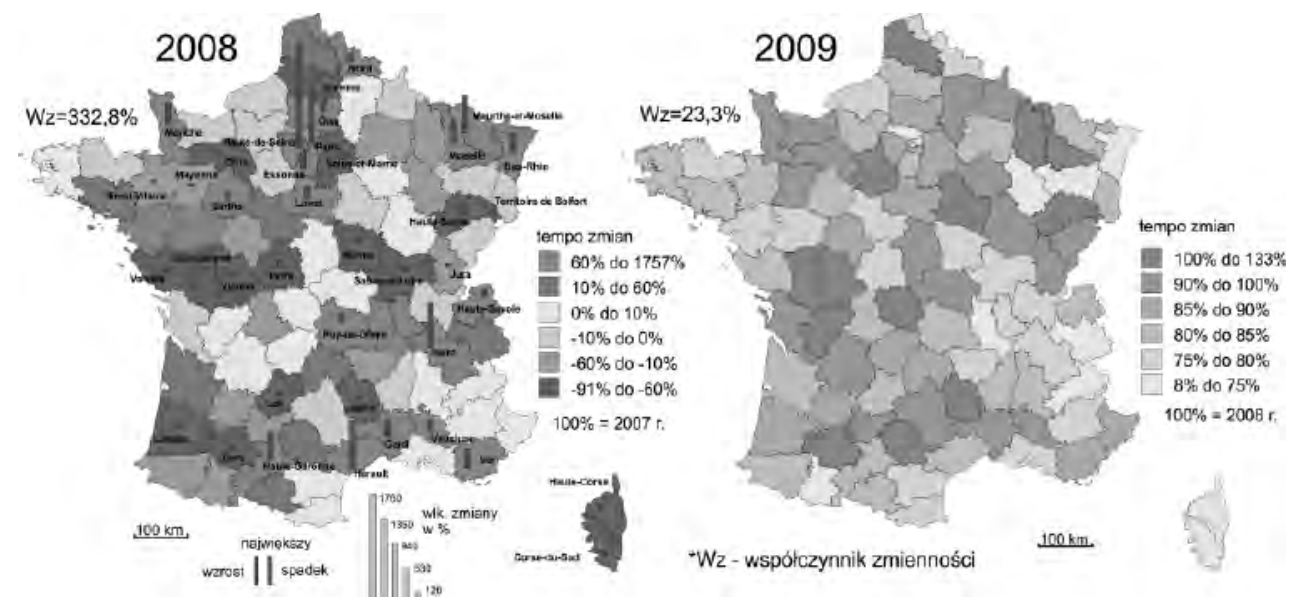

Źródło: opracowanie własne na podstawie danych APCE.

W 2009 wszystkie departamenty doświadczyły wzrostu w stosunku do 2008. Zróżnicowanie między departamentami było już ponad stukrotnie mniejsze niż w roku poprzednim. W przytoczonym okresie regiony o największym wzroście nowych podmiotów gospodarczych nie pokryły się z tymi z roku ubiegłego. Najlepiej można zaobserwować tę sytuację, porównując dane standaryzowane dla liczby nowo powstałych firm w latach 2008 i 2009 (ryc. 4). 
W ok. 40 przypadkach departamenty, które odnotowały spadek lub wzrost w roku 2008, w późniejszym czasie były odpowiednio powyżej lub poniżej wartości średniej dla kraju. Można zatem przypuszczać, że poprawa sytuacji gospodarczej (lub zahamowanie spadku) wraz z podjętymi działaniami rządu przyczyniły się do aktywizacji regionów peryferyjnych. Odnosząc się do całego okresu od początku kryzysu światowego do roku 2012, można zauważyć, że we Francji rozwój nowych firm następował głównie poza centrum kraju. Największym ośrodkiem inicjatyw gospodarczych pozostawał Paryż i departamenty jego metropolii. Ponadto wyróżniały się regiony południowe (region Lyonu, Alpy-Prowansja-Lazurowe Wybrzeże). Wysokimi wartościami odznaczały się również departamenty nadatlantyckie (ryc. 5A).

Ryc. 4. Standaryzowane tempo zmian liczby nowo powstałych firm w latach 2008 i 2009 w departamentach Francji

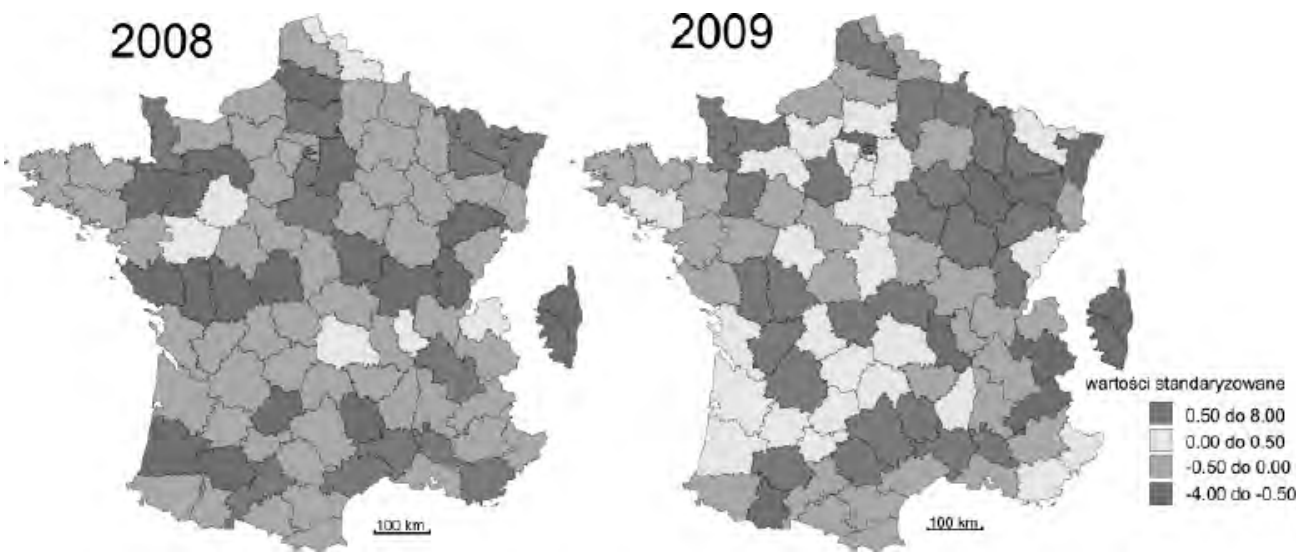

Źródło: opracowanie własne na podstawie danych APCE.

Ryc. 5. Średnia liczba nowo powstałych firm (A) oraz tempo ich zmian (B) w latach 2008-2012 w departamentach Francji

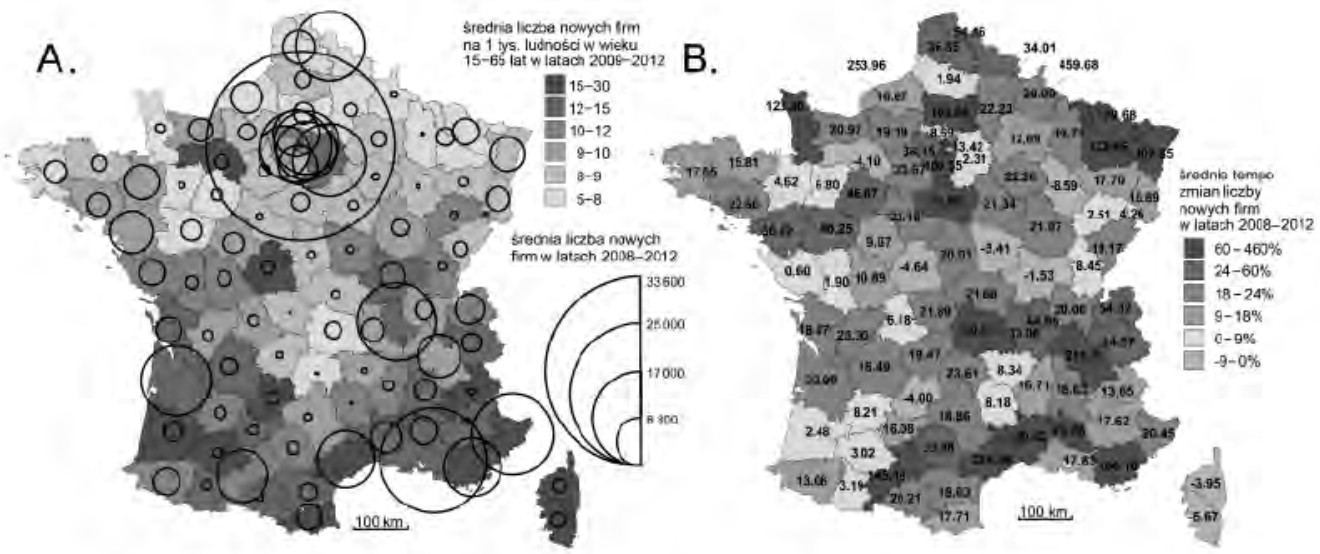

Źródło: opracowanie własne na podstawie danych APCE. 
Jak już wspomniano, wysoki odsetek nowo rejestrowanych firm generowany był głównie przez aktywną postawę ludności (znaczący udział mają w tym wypadku również emigranci spoza Europy - analogicznie do roli ludności hinduskiej w Wielkiej Brytanii). Co więcej, położenie nadmorskie i tradycje związane $\mathrm{z}$ handlem stanowią historyczne uwarunkowania przedsiębiorczości głównie w miastach portowych ${ }^{1}$. Innym czynnikiem jest rozwój sektora innowacyjnego na południu Francji. Odnosząc się do wartości względnych w liczbie nowo utworzonych firm w przeliczeniu na tysiąc mieszkańców aktywnych ekonomicznie, tj. w wieku od 15 do 65 lat, również uwidacznia się wyraźna supremacja części południowej nad północną. Analizując natomiast tempo zmian liczby nowo zarejestrowanych podmiotów gospodarczych w departamentach Francji w rozpatrywanym okresie, wartości powyżej 100\% odnotowały departamenty metropolii paryskiej, Alzacji i Lotaryngii, Prowansji i Langwedocji, departamenty ośrodków innowacyjnych (Grenoble, Tuluza, Technopole Cherbourg Normandie) oraz departamenty ośrodków usługowych z dużym udziałem firm MŚP (Oise) (ryc. 5B). W dużej mierze tak wysokie wartości departamenty te zawdzięczają wzrostowi występującemu na początku kryzysu, podczas którego wiele regionów peryferyjnych odnotowało duży spadek.

W celu dokładniejszej analizy postaw przedsiębiorczych w dalszej części publikacji odniesiono się do samozatrudnienia (auto-entrepreneur). System ten stworzono na podstawie ustawy o modernizacji gospodarki z 4 sierpnia 2008 r., traktując go jako odpowiedź na wzrastające bezrobocie i recesję gospodarki francuskiej. Preferencyjne finansowania dla samozatrudnienia miały zredukować koszty produkcji. Firmami zaliczonymi do grupy auto-entrepreneur były wszystkie przedsiębiorstwa jednoosobowe, których roczny obrót nie przekraczał 81500 euro dla handlu i gastronomii oraz 32600 euro dla innych usług.

W przestrzennym zróżnicowaniu liczby nowo powstałych firm jednoosobowych w latach 2009-2012 uwidacznia się wyraźna preponderancja regionu Paryża i śródziemnomorskich departamentów południowych oraz regionu akwitańskiego. Najniższe wartości miały zaś regiony Francji centralnej i północnej (ryc. 6A). Spośród nowo powstałych firm najczęściej były to podmioty z sektora usług oraz transportu, zakwaterowania i wyżywienia. Duży udział wykazywały także przedsiębiorstwa z branży budowlanej (ryc. 6B).

Ryc. 6. Liczba nowo powstałych firm jednoosobowych (A) oraz ich struktura (B) w latach 2009-2012 w departamentach Francji

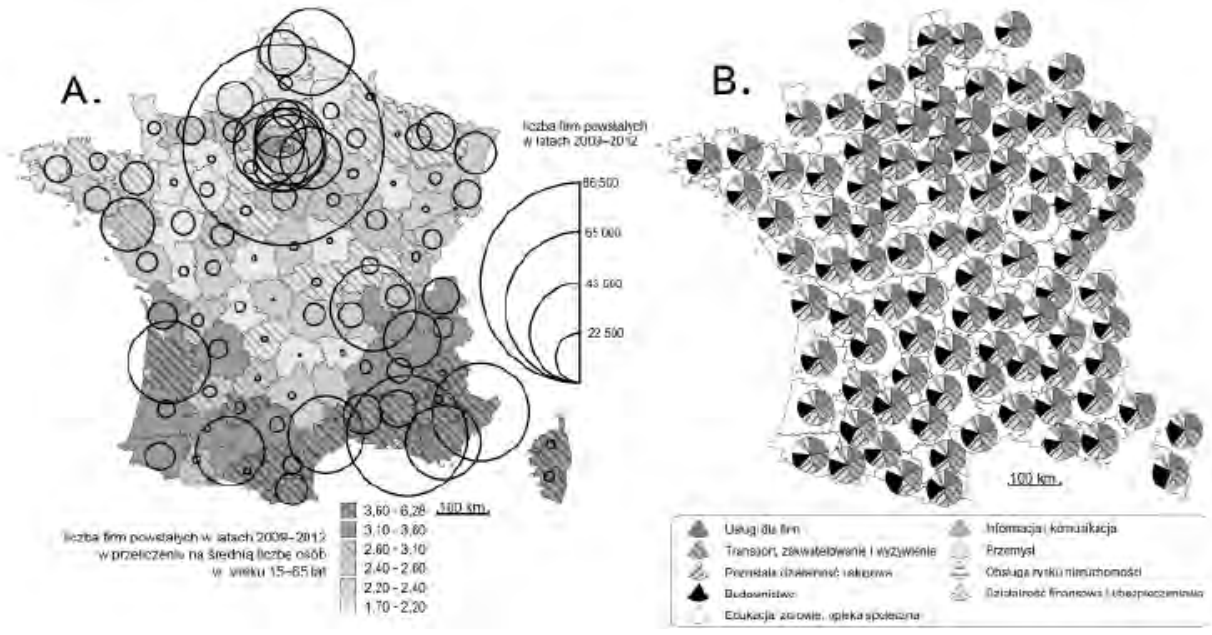

Źródło: opracowanie własne na podstawie danych APCE.

\footnotetext{
${ }^{1}$ Większej aktywności ekonomicznej społeczeństw obszarów nadmorskich można również doszukiwać się w teoriach geopolitycznych, cywilizacji morza i lądu (Eberhardt, 2009).
} 
W podobny sposób tempo zmiany liczby nowo powstałych firm jednoosobowych, określane poprzez nachylenie linii trendu, wykazuje duże zróżnicowanie departamentalne (ryc. 7A). Uzewnętrznienie tendencji wzrostowych wykazywały departamenty zachodnie i południowe Francji. W grupie tej znalazły się jednostki zlokalizowane w pasie od Bretanii po Alpy i Prowansję. Tendencje spadkowe wykazywały natomiast rozwinięte departamenty północne, od Alzacji po górną Normandię i Pikardię. Można zatem zaryzykować stwierdzenie, że trend wzrostowy względem liczby rejestracji nowych mikroprzedsiębiorstw miały jednostki odznaczające się dotychczas niewielką liczbą nowych firm. Wystąpiła zatem ujemna współzmienność pomiędzy średnią liczbą nowych firm a trendem ich zmiany, jednak niedostrzegalna jest ta zależność w przeliczeniu liczby nowych firm na liczbę mieszkańców (ryc. 7B). W tym względnym ujściu tempa zmian prawie wszystkie departamenty przejawiały tendencję spadkową, najsilniej widoczną w południowo-zachodniej Francji.

Ryc. 7. Trend zmiany liczby nowo powstałych firm jednoosobowych w latach 2009-2012 (A) oraz zależność pomiędzy liczbą nowo powstałych firm (1 000 os. w wieku 15-65 lat) a tendencją ich zmian w latach 2009-2012 (B) w departamentach Francji
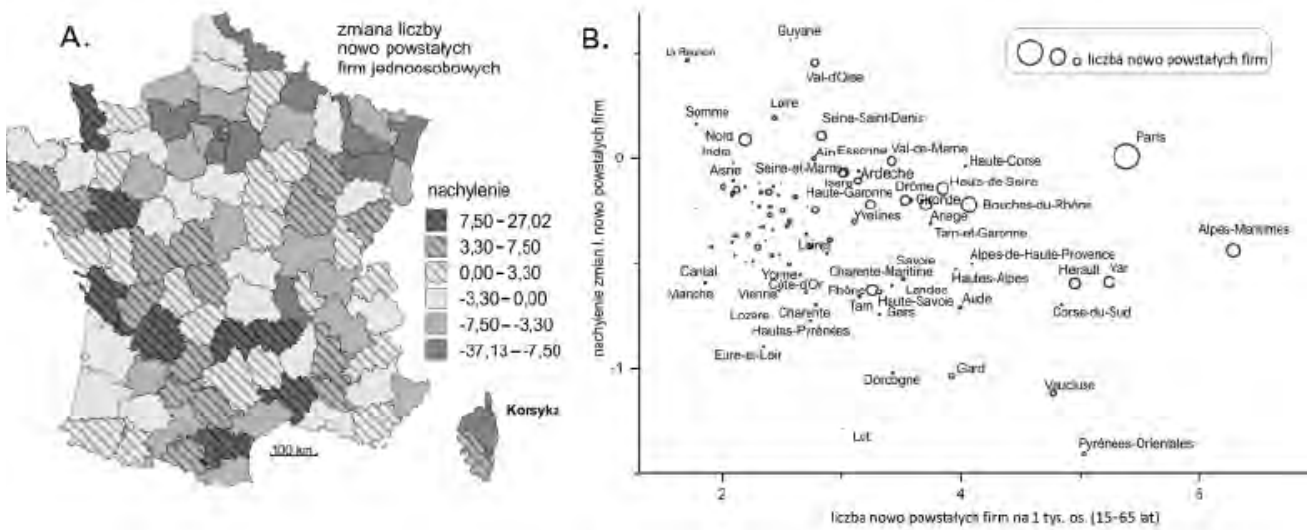

Źródło: opracowanie własne na podstawie danych APCE.

Odnosząc się do zmiany udziału poszczególnych sektorów w nowo tworzonych przedsiębiorstwach jednoosobowych w departamentach Francji, można uznać, że w wypadku budownictwa, edukacji, opieki zdrowotnej i społecznej oraz przemysłu większość jednostek zanotowała w badanym okresie wzrost (ryc. 8). Przy czym udział firm z sektora budowlanego w największym stopniu wzrósł w północno-wschodniej Francji, udział firm z sektora edukacji, usług medycznych i społecznych - na południu, natomiast sektora przemysłu w centrum kraju. Największy spadek udziału wśród nowych podmiotów jednoosobowych odnotowały firmy z branży usług oraz informacji i komunikacji. Ubytek ten odnosił się prawie do całego terytorium Francji. W wypadku pozostałych sektorów zróżnicowanie przestrzenne tempa zmian nowych firm było nader duże.

W podsumowaniu dokonano próby zestawienia wybranych wskaźników społeczno-ekonomicznych departamentów Francji ze średnią liczbą nowo powstałych firm jednoosobowych w latach 2008-2012. Jak można zauważyć na ryc. 9, najwyższe wartości korelacji wykazywała wielkość rejestracji nowych firm z udziałem rzemieślników, kupców i przedsiębiorców w społeczeństwie departamentu $(0,59)$, udział obcokrajowców spoza UE $(0,46)$ oraz udział 
Ryc. 8. Zmiany udziału nowo powstałych firm jednoosobowych wg sektorów w latach 2009-2012 (nachylenie linii trendu)

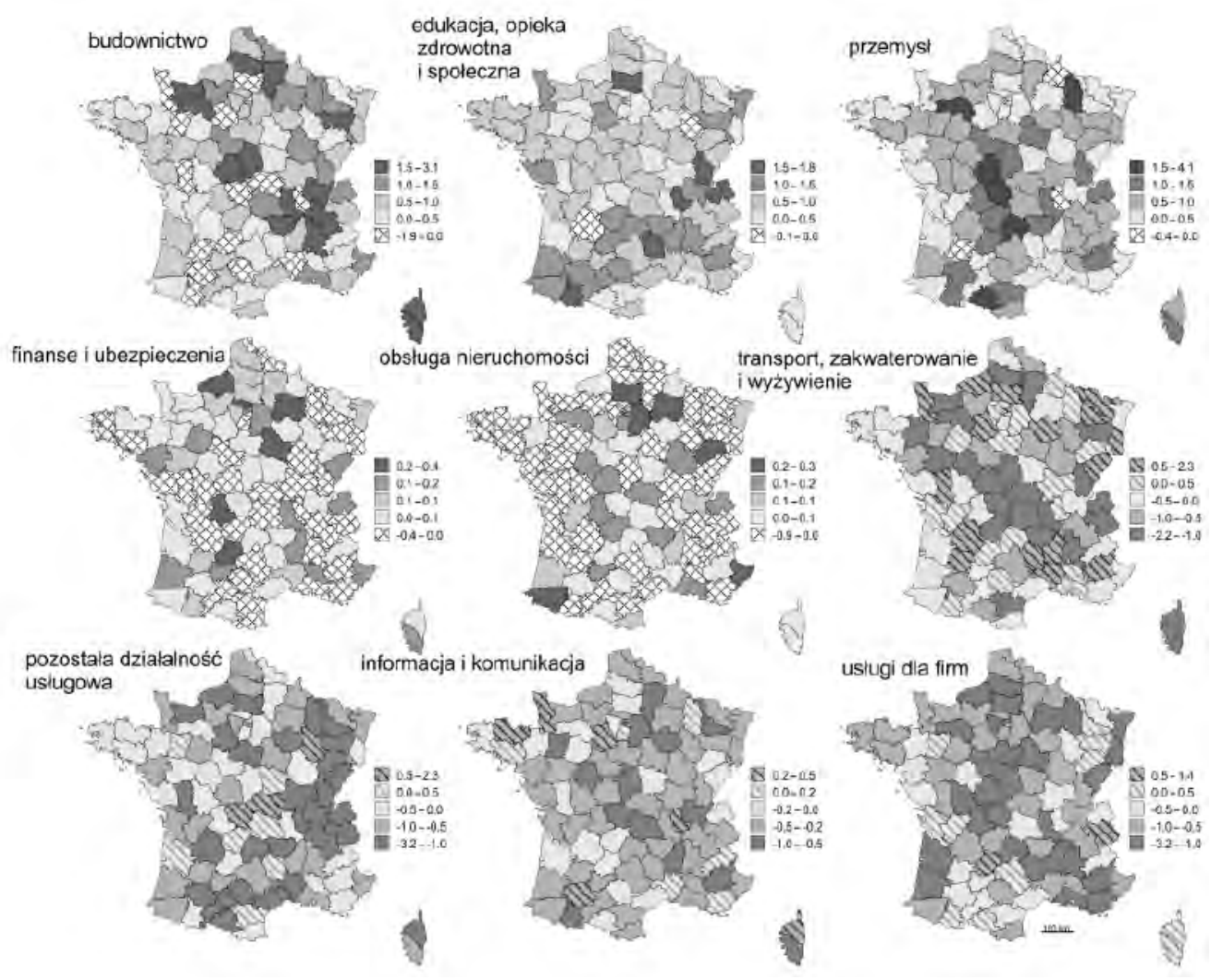

Źródło: opracowanie własne na podstawie danych APCE.

ludności z wykształceniem wyższym $(0,41)$. Wyniki te wydają się potwierdzać, że przedsiębiorczość przejawiająca się aktywną postawą związaną z samozatrudnieniem jest cechą społeczeństw, które w procesach historycznych rozwinęły ducha przedsiębiorczości. Ludność w regionach o długich tradycjach firm rodzinnych wydaje się predysponowana do prowadzenia własnego biznesu. Drugim elementem jest udział obcokrajowców spoza Europy, w tym z Afryki i Azji, czyli regionów, w których tradycje prywatnej działalności rzemieślniczej i handlowej są bardzo silne. I tym wypadku można mówić o duchu przedsiębiorczości i tzw. wiedzy milczącej (tacit knowledge). Natomiast w przypadku ludzi z wyższym wykształceniem dodatnia zależność z wielkością samozatrudnienia może wynikać z przygotowania tej grupy do działań przedsiębiorczych, przyswojonego w toku nauki (wyposażenie w potrzebną wiedzę i umiejętności). Ponadto osoby z wyższym wykształceniem mogą mieć inne przydatne umiejętności nabyte w czasie nauki, np. kwalifikacje komputerowe, wpływające w pewnym stopniu na większą aktywność zawodową (m.in. posługiwanie się rejestracją komputerową, wyszukiwanie informacji w internecie, obsługa programów księgowych). Dodatkowo, w odniesieniu do teorii Richarda Floridy, ludność z wyższym wykształceniem stanowi klasę kreatywną zarówno w sferze kreowania innowacji, jak i aktywności biznesowej (Lee, Florida, Acs, 2004). 
Ryc. 9. Wielkość korelacji średniej liczby nowo powstałych firm jednoosobowych w latach 2009-2012 z wybranymi wskaźnikami społeczno-ekonomicznymi dla lat 2008-2010

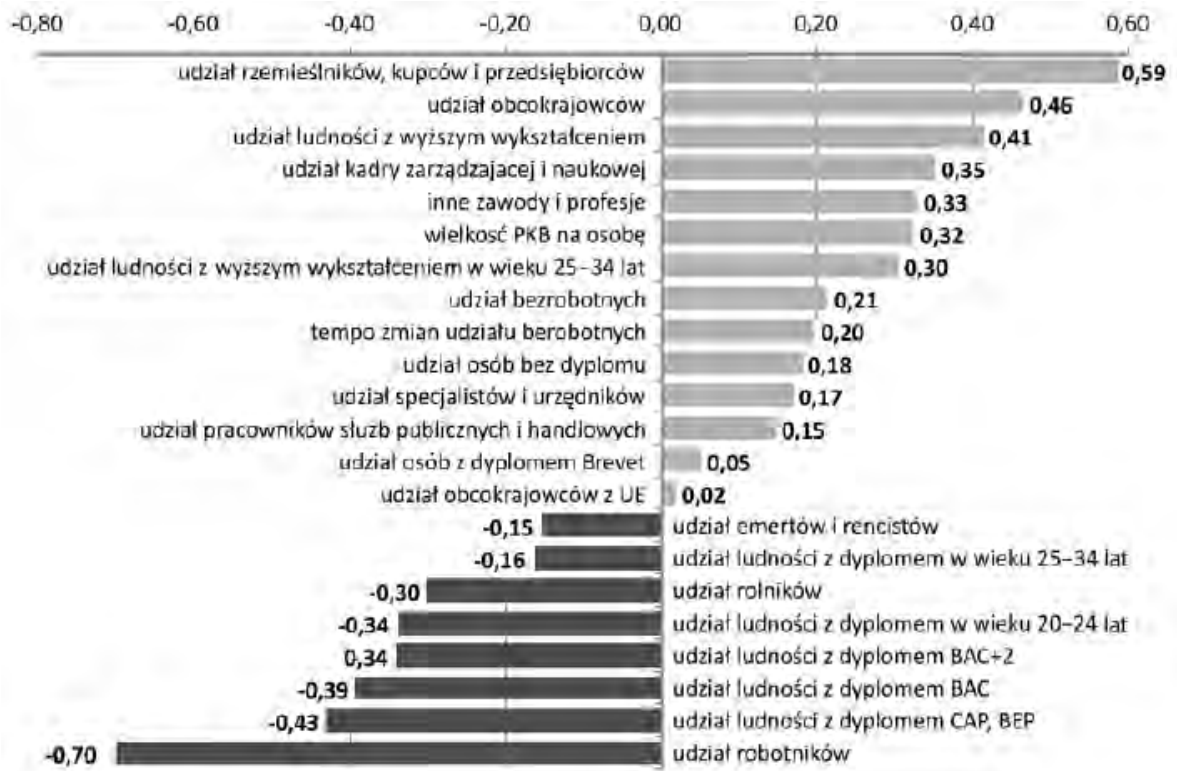

Źródło: opracowanie własne na podstawie danych APCE i Insee.

Jak widać z krzywych regresji wykreślonych dla najbardziej zależnych obserwacji (ryc. 10), to właśnie udział ludności związanej z MŚP w społeczeństwie departamentalnym oraz odsetek osób z wyższym wykształceniem w największym stopniu współzależą z liczbą nowo zakładanych podmiotów. Natomiast udział obcokrajowców charakteryzuje się małą istotnością statystyczną.

Ryc. 10. Linie regresji średniej liczby nowo powstałych firm jednoosobowych w latach 2009-2012 z wybranymi wskaźnikami społeczno-ekonomicznymi dla lat 2008-2010
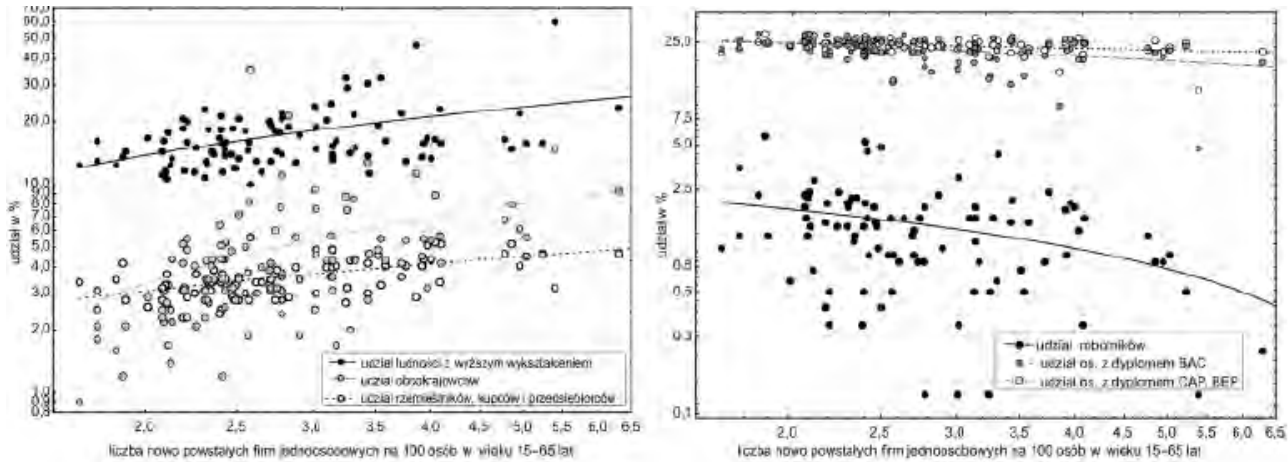

Źródło: opracowanie własne na podstawie danych APCE i Insee. 
W wypadku ujemnej zależności najmniejsze wartości przyjmuje udział robotników w społeczeństwie departamentu oraz udział ludności z podstawowym wykształceniem zawodowym $(\mathrm{BAC}, \mathrm{CAP} \text { i BEP})^{2}$. Wartości te wydają się potwierdzać wcześniejsze spostrzeżenia o relewantnym wpływie poziomu wykształcenia społeczeństwa i tradycjach zawodowych w nim panujących na poziom przedsiębiorczości. Przy czym z analizy regresji widać, że bardziej istotny wydaje się poziom wykształcenia ludności, niż udział osób pracujących na umowę.

\section{Wnioski}

W powyższym tekście podjęto próbę przedstawienia uwarunkowań kształcenia z zakresu przedsiębiorczości oraz odpowiedzi na pytanie o przestrzenne zróżnicowanie postaw przedsiębiorczych we Francji. Na podstawie przeprowadzonych badań należy stwierdzić, że pomimo licznych zmian w nauczaniu przedsiębiorczości, które wprowadzono w ostatnich latach, ale ograniczonych prawie wyłącznie do szkolnictwa wyższego, wydają się one niedostateczne, zwłaszcza w odniesieniu do współczesnych wyzwań gospodarczych i cywilizacyjnych. W celach nauczania przedsiębiorczości zaobserwować można silniejszy nacisk na kształtowanie postaw przedsiębiorczych młodzieży oraz stymulowanie rozwoju ich naturalnych cech, mogących stanowić o konkurencyjności na rynku pracy, niźli na przekazywanie „suchej” wiedzy ekonomicznej. Również działania metodą projektów przy kooperacji z instytucjami pozaszkolnymi (specjalistami, przedsiębiorcami, firmami) wydają się kongruentnym wyborem.

Pomimo postępującej od XIX w. unifikacji nauczania, we Francji w dalszym ciągu istnieją znaczące dysproporcje w przejawach przedsiębiorczości (na potrzeby badań przyjęto, że jednym z nich jest zakładanie nowych podmiotów gospodarczych). Nierówności w tym temacie najsilniej uwidoczniły się w sytuacji ekstremalnej - z rozpoczęciem się światowego kryzysu finansowego w 2008 r. Jednak również w późniejszym okresie najbardziej przedsiębiorczymi obszarami pozostawały regiony dużych ośrodków miejskich, będących zarówno biegunami wzrostu gospodarczego, jak i miejscami imigracji ludności kreatywnej (drenaż mózgów). Również regiony z dużym udziałem sektora wysokiej techniki w swej gospodarce wykazywały dużą aktywność na polu tworzenia samozatrudnienia. Przyczyną takiego stanu może być nie tylko dynamiczny rozwój firm innowacyjnych, lecz także znaczny odsetek ludności z wyższym wykształceniem. Ostatnim typem departamentów, które w badanym okresie odznaczały się zauważalnym przyrostem nowych firm, były obszary nadmorskie. W tym wypadku należy odnieść się do tradycji związanych z handlem oraz aktywnej postawy społeczeństw i ich otwartości na zmiany.

Powyższe obserwacje zostały potwierdzone przez zestawienie danych o wielkości nowo powstałych firm z danymi o udziale MŚP w gospodarce jednostek oraz udziale ludności z wyższym wykształceniem.

Reasumując, należy stwierdzić, że kształcenie z zakresu nauki, a w szczególności kształtowania postaw przedsiębiorczych, wydaje się istotnym czynnikiem wpływającym na skalę przedsiębiorczości obywateli. Proces kształtowania ducha przedsiębiorczości powinien być realizowany w sposób ciągły i kompleksowy, przez otaczające wzorce i w odniesieniu do wszystkich aspektów codziennego życia. Dlatego przedsiębiorczość powinna być praktykowana w szkołach przez ludzi przedsiębiorczych, w procesie osiągania konkretnych celów.

Czy zatem Francuzi są narodem przedsiębiorczym? Niestety, na tle Europy dane dotyczące aktywności w sferze małego i średniego biznesu przemawiają na ich niekorzyść (Phelps, Zoega, 2009). Także działania podjęte na rzecz wprowadzenia kursów z przedsiębiorczości

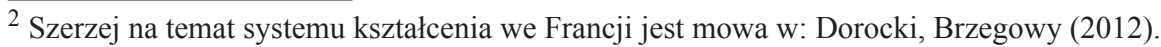


na niższych szczeblach edukacji spotkały się z falą krytyki dużej części społeczeństwa. Jednakże fakt coraz silniejszego wzrostu znaczenia małych i średnich firm w gospodarce światowej, zwłaszcza w ujęciu ich innowacyjności, stawia przed szkolnictwem Republiki duże wyzwanie. Konkludując, warto przywołać spostrzeżenie współzałożyciela Actelion, Jean-Paula Clozela, który zauważył, iż bycia przedsiębiorcą nie można się nauczyć, albowiem nie ma szkoły, która edukuje, jak być odważnym (600 leaders phosphorent sur l'emploi de demain). Dlatego tak ważne jest, aby zarówno w sytuacji wzrostu bezrobocia spowodowanego kryzysem światowym, jak i nasilającego się procesu delokalizacji oraz restrukturyzacji gospodarki Francji kształcić nowych twórców biznesu. Liderów mających nie tylko wiedzę, ale przede wszystkim l'esprit d'entreprise.

\section{Literatura \\ References}

600 leaders phosphorent sur l'emploi de demain (2006), http://www.hebdo.ch/leaders_phosphorent_ sur_lemploi_de_demain_23054_.html

Bechard, J.-P. (1998). L'enseignement en entrepreneurship à travers le monde: validation d'une typologie. Management International, 3(1), 25-34.

Brzozowski, T. (2007). „Przedsiębiorczość” - pojęcie polisemiczne czy niewłaściwie rozumiane? Próba systematyzacji. Przedsiębiorczość - Edukacja, 3, 196-203.

Davezies, L. (2012). La crise qui vient: La nouvelle fracture territorial. Paris: Seuil.

Dorocki, S. (2011). Wpływ kryzysu gospodarczego na przemiany struktur regionalnych Francji. Prace Komisji Geografii Przemystu Polskiego Towarzystwa Geograficznego, 17, 67-86.

Dorocki, S., Brzegowy, P. (2012). Regionalne zróżnicowanie kształcenia we Francji w aspekcie rozwoju przedsiębiorczości departamentów zamorskich. Przedsiębiorczość - Edukacja, 8, 229-258.

Dorocki, S., Kilar, W., Rachwał, T. (2011). Założenia i cele Projektu „Krok w przedsiębiorczość” dla nauczycieli szkół ponadgimnazjalnych. Przedsiębiorczość - Edukacja, 7, 308-320.

Eberhardt, P. (2009). Koncepcje geopolityczne Karla Haushofera. Przegląd Geograficzny, 81 (4), 527-549.

Fayolle, A. (2000). L'enseignement de l'entrepreneuriat dans le système éducatif supérieur français: un regard sur la situation actuelle. Gestion 2000, 17(2), 77-95.

Kurek, S., Rachwał,T. (2010). Założenia i wstępne wyniki europejskiego projektu badawczego FIFOBI w zakresie kształtowania kompetencji uczniów gimnazjum do prowadzenia działalności gospodarczej. Przedsiębiorczość - Edukacja, 6, 472-485.

La destruction de l'esprit d'entreprise en France 01/07/2013, http://www.contribuables.org/2013/07/01/ la-destruction-de-lesprit-dentreprise-en-france/.

Lavoie, L. (2013). France: l'esprit d'entreprise entre à l'école. 17 juin 2013, http://cursus.edu/article/20342/ france-esprit-entreprise-entre-ecole/.

Lee, S.Y., Florida, R. \& Acs, Z. (2004). Creativity and entrepreneurship: a regional analysis of new firm formation. Regional Studies, 38(8), 879-891, DOI: 10.1080/0034340042000280910.

Marchesnay, M. (2008). Trente ans d'entrepreneuriat et PME en France: naissance, connaissance, reconnaissance. Revue internationale P.M.E.: économie et gestion de la petite et moyenne entreprise, 21 (2), 145-168.

Naudé, W. (2008). Entrepreneurship in Economic Development. Research Paper 20, 1-47.

Phelps, E., Zoega, G. (2009). Entrepreneurship, culture and openness. W: D.B. Audretsch, R. Litan, R. Strom (red.), Entrepreneurship and Openness: Theory and Evidence, Cheltenham: Edward Elgar Publishing, 101-130.

Rachwał, T. (2005a). Kształtowanie postaw uczniów na lekcjach przedsiębiorczości. W: Przedsiębiorczość a współczesne wyzwania cywilizacyjne. Przedsiębiorczość - Edukacja, 1, 137-144.

Rachwał, T. (2005b). Podstawy przedsiębiorczości. Słownik. Warszawa: Nowa Era.

Rachwał, T. (2006). Kształtowanie postaw przedsiębiorczych w edukacji szkolnej. W: B. Suchacka (red.), Szkoła w nauce i praktyce edukacyjnej, t. II, Kraków: Oficyna Wydawnicza „Impuls”, 427-434. 
Senicourt, P., Verstraete, T. (2000). Apprendre à entreprendre: typologie à quatre niveaux pour la diffusion d'une culture entrepreneuriale au sein du système éducatif. Reflets et perspective de la vie économique, 39(4), 131-140.

Tounés, A. (2003). Un cadre d'analyse de l'enseignement de l'entrepreneuriat en France. Cahier de recherche du réseau Entrepreneuriat de l'AUF, 3-69, 1-15.

Visot, M. (2013). Fleur Pellerin: «Je souhaite créer une école de l'entrepreneuriat» 26.08.2013 Le Figaro.fr http://www.lefigaro.fr/entrepreneur/2013/08/26/09007-20130826ARTFIG00434-fleur-pellerin-je-souhaite-creer-une-ecole-de-l-entrepreneuriat.php.

Zioło, Z. (2006). Rola przedsiębiorczości w podnoszeniu konkurencyjności społeczeństwa i gospodarki. Przedsiębiorczość - Edukacja, 2, 10-17.

Zioło, Z. (2007). Rola przedsiębiorczości w aktywizacji gospodarczej - zarys modelu. Przedsiębiorczość - Edukacja, 3, 10-17.

Zioło, Z. (2008). Ekonomiczne i społeczne uwarunkowania rozwoju gospodarki opartej na wiedzy. Przedsiębiorczość - Edukacja, 4, 12-23.

Sławomir Dorocki, dr, Uniwersytet Pedagogiczny im. Komisji Edukacji Narodowej w Krakowie. Absolwent studiów z zakresu geografii społeczno-ekonomicznej, doktor nauk humanistycznych w dyscyplinie historia (Instytut Europeistyki - Uniwersytet Jagielloński). Adiunkt w Instytucie Geografii Uniwersytetu Pedagogicznego im. Komisji Edukacji Narodowej w Krakowie. Zainteresowania badawcze autora skupiają się wokół problematyki regionów i procesów regionalizacji społeczno-gospodarczej, ze szczególnym uwzględnieniem zróżnicowania przestrzeni europejskiej oraz procesów integracji europejskiej i uwarunkowań historycznych.

Sławomir Dorocki, graduated from Pedagogical University in Krakow MA degree in geography, $\mathrm{PhD}$ in history (Institute of European Studies of the Jagiellonian University). Adiunkt (assoc. professor) at Pedagogical University of Cracow, Institute of Geography. His research interests are tied with regional problems and processes of socio-economic regionalization, with particular emphasis on the diversity of Europe, processes of European integration and historical conditions.

Pawel Brzegowy, absolwent Instytutu Nauk Politycznych i Stosunków Międzynarodowych Uniwersytetu Jagiellońskiego, doktorant w Instytucie Geografii Uniwersytetu Pedagogicznego im. Komisji Edukacji Narodowej w Krakowie.

Główne zainteresowania badawcze autora dotyczą historii społecznej i gospodarczej departamentów oraz wspólnot Francji pozaeuropejskiej, a także galicyjskiej kultury zdrojowiskowej w XIX i XX w.

Pawel Brzegowy, graduate of the Institute of Political Studies and International Relations at the Jagiellonian University, doctoral student at the Faculty of Geography at the Pedagogical University of Cracow named after the National Education Commission. Main research interests focused on social and economic history of extra-European France departments and communities.

Adres/Address: Sławomir Dorocki, Paweł Brzegowy

Uniwersytet Pedagogiczny im. Komisji Edukacji Narodowej w Krakowie

Instytut Geografii

ul. Podchorążych 2, 30-084 Kraków, Polska

e-mail: sdorocki@up.krakow.pl

e-mail: pawel.brzegowy@uj.edu.pl 